\title{
Hybridity in Meja Mwangi's Little White Man
}

\author{
Elizabeth A. Odhiambo \\ School of Humanities and Social Sciences \\ Bondo University, Box 210- 40601, Bondo. \\ Email: e.achieng39@yahoo.com
}

\section{Doi:10.5901/mjss.2013.v4n6p267}

\section{Abstract}

The study examined elements of hybridity in Meja Mwangi's Little White Man, a text set in colonial Kenya. In particular, the study was interested in the writer's juxtaposition of the world of the child characters with that of the adult characters and the hybrid syncretic crossings reflected therein, against the backdrop of colonialism. The postcolonial theory was useful in the analysis of the selected text. The findings reveal that the text reflects both cultural and character hybridity. For the child characters, hybridity is a site for social reconstruction from which they emerge wiser and more enlightened through social interaction and practical experience of each other's world. The adult world on the contrary, stands in total contrast to the children's world. It is characterized by suspicion, insecurity, tension, contempt, violence and racial prejudice. It largely revolves around the interplay of power relations with the colonial settler at the top and the natives at the bottom. At interpersonal level, the adults always impose their will on the children. In effect, colonization is depicted at two levels in that, the Africans are colonized by the whites and secondly, the children are colonized by the adults who deny them the freedom to pursue their personal interest. It is notable however, that even under such strict conditions; the children always maneuver their way around the adults so as to pursue their own interests. This they do through being noncommittal, giving excuses and vague responses as in the case of Kariuki, the protagonist.

Keywords: Hybridity, Meja Mwangi, Little, Whiteman

\section{Introduction}

African children's books reflect the tension between creating truly national identities and celebrating unique cultures in nations artificially created from disparate peoples by European cartographers (Khorana, 1998). As a result of the experience of colonialism, hybrid elements are present in all postcolonial literatures - children's literature inclusive. Hybridity commonly refers to the creation of new transcultural forms within the contact zones produced by colonization (Laragy, 2008).

As Sharp (2008) observes, postcolonialism demonstrates a heterogeneity of colonized places by analyzing the uneven impact of Western colonization on different places, peoples and cultures. This is done by engaging with the variety of ways in which 'relations, practices and representations' of the past is 'reproduced or transformed', and studying the connections between the 'heart and the margins' of the empire (Sharp, 2008).Of note too, is the fact that while many writers living and writing from within those previously colonized nations may still write in response to colonialism, many writers and critics choose to look to the present or the future. The postcolonial field is thus a field in which everything is contestable, from one's reading of a text to one's personal, cultural, racial, national standpoint, perspective and history (Punter, 2000).

Meja Mwangi's text Little White Man clearly illustrates the interaction between the colonized and the colonizer. Rose (1984) propounds that children's fiction is impossible, not because it cannot be written but because it is based on a contradiction purporting to be about children when it is really about adults who figure the children for their own purposes as a space where the anxieties of adulthood can be held at bay. Against the insecurities of sex, language and existence, the figure of the child stands as a bulwark: a secure point that occludes doubt.

The contradictions cited by Rose actually find credence in Meja Mwangi's Little White Man. The text is a depiction of the impact of the colonialism in Kenya told from the perspective of Kariuki, the child narrator. The story's setting, events and choice of characters all result to the creation of a hybrid text that though labeled children's literature actually addresses very mature issues. 


\section{Theoretical framework}

The study was guided by the post colonial theory. This theory deals with the writing and reading of literature written in previously or currently colonized countries or literature written in colonizing countries which deals with colonization or colonized people. Notable theoreticians in this field include Edward Said, Gayatri Spivak and Homi Bhabha among others.

The theory focuses particularly on the way in which literature by the colonizing culture distorts the experience and realities, and inscribes the inferiority of the colonized people. It also focuses on literature by the colonized people which attempts to articulate their identity and reclaim their past in the face of that past's inevitable 'otherness.' It can also deal with the way in which literature in colonizing countries appropriates the language, images, scenes, tradition and so forth in colonized countries (Lye, 1998).

For the purpose of this study emphasis was laid on the comprehensive comparative model of post colonial literature which argues for features such as hybridity and syncretism as constitutive elements of all postcolonial literatures.

\section{Literature Review}

Various critics have examined Meja Mwangi's literary works. However their concern has majorly lain with his adult fiction. Kehinde (2005) examines the image of post colonial Africa in Meja Mwangi's Going Down River Road. She concludes that the novel mirrors the socio political situation of most Africa nations immediately after independence in a somewhat uncritical manner. In her view, Going Down River Road is an implicit endorsement of the established order it appears to be interrogating.

In another critic, Kehinde (2004) examines the discourse of postcolonial decadence in Contemporary African fiction with reference to Meja Mwangi's Kill me Quick. She observes that in the text, Mwangi imaginatively captures post colonial pains in African nations with apt narrative devices. Both studies however differ with the current in that in the current research, interest lay in children's fiction.

Of note however is the fact that hardly any critical attention has been given to his children's fiction. Lori Walker (2005) does a review on Little White Man then titled The Mzungu Boy. She merely gives the synopsis of the tale citing a few characteristics that makes the text an ideal choice for classroom reading.Like Lori Walker, McGuire (2008) merely gives an overview of Meja Mwangi's literary career. With regard to Little White Man, she only gives a review of the story.

It is on basis of such limited critical attention that the current study examined the elements of hybridity in Meja Mwangi's fiction.

\section{Methodology}

The research was mainly qualitative. It was conducted through an analytical research design. Analytical research, as a style of qualitative inquiry is a non interactive document research which describes and interprets the past or recent past from selected sources (Macmilliam \& Schumaher, 1997). These sources may be documents preserved in collections or participant's oral testimonies or as in the case of this research, a literary text of an author. This design is ideal in a situation where a researcher attempts to analyze a situation and make evaluation. For the present research, it was instrumental in examining how hybridity is reflected in Meja Mwangi's Little White Man.

\subsection{Data Collection Techniques}

The study was mainly library based. It began with a preliminary study of the available related literature in the library which formed the basis for secondary data.

The primary data was generated through content analysis of the selected text. Nachmias (2009) defines content analysis as any technique for making inferences by systematically and objectively identifying specified characteristics of messages. Qualitative content analytical approaches focus on analyzing both the explicit or manifest content of a text as well as interpretations of latent content of texts- that which can be interpreted or interpolated from the text, but is not explicitly stated in it (Granhein \& Lundman, 2003).

In the current research, reading, analysis and interpretation of the selected text was done to identify the hybrid elements depicted therein. This process was accomplished through use of the postcolonial theory. 


\subsection{Data Analysis}

The data collected through content analysis of the selected texts was be coded according to thematic concerns, the mode of characterization and vision of the author. The postcolonial theory, particularly the more comprehensive comparative model which argues for features such as hyridity and syncreticity as constitutive elements of all postcolonial literatures was applied in the textual analysis to establish the hybrid syncretic crossings in the author's works.

\section{Premises of Hybridity}

Meja Mwangi's Little White Man is a merging of two worlds, The world of the colonized and that of the colonizer. This is juxtaposed with the children's world. Mwangi not only draws a comparison between the adults' experience and the children's experience but his choice of child characters is also representative of two worlds by virtues of their different races. Thus the text is a depiction of multiple level of hybridity developed against the backdrop of colonization.

In the adult world the effect of the disrupting experience of colonialism is portrayed through the eyes of Kariuki a young boy of twelve years. The oppressive nature of the colonial master and his administration is visited right at the beginning of the text. The villagers wake up to find themselves surrounded by hundreds of heavily armed white soldiers. Everybody is herded into the cattle pen outside the village and forced to sit on fresh cow dung. Ironically they were ignorant of whatever crime they had committed. It later turns out that the white master Bwana Ruin's riffle had disappeared and was said to have been stolen by the Mau Mau.

In the meantime the white soldiers ransack the village huts and steal whatever money and valuables they could unearth. They thus make away with the workers' pay paid to them the previous day. The colonizer thus partakes in the crime the colonized is accused of. The only difference lies in the fact those soldiers by virtue of their race are not accountable to the blacks.

Both the adults and children are subjected to dehumanization, they are kept in the cattle enclosure till the sun comes up, bright and hot before being addressed by Bwana Ruin. Unmoved by the children's complaints of hunger, the soldier do not release their captives or tell them what they wanted of them. Only Kariuki's father, the cook, the herdsmen and the milk men were saved from this ordeal because they offered essential services to Bwana Ruin.

In his address, Bwana Ruin's reference to the blacks as 'watu,' implying 'people' denies them a sense of identity and inscribes his superiority. His accusations are blanket condemnation from which no one is exempted - they once stole his milk, his wheat, his fruits and now his riffle. The Mau Mau had stolen his rifle and for him all black people are Mau Mau. His superiority over the black crowd is wisely summed up by Kariuki in whose view Ruin had the' voice and authority of God'(p2). His height too enhances this superiority - Ruin was taller than anyone Kariuki knew.

The relationship between the adults and the children mirrors that between the white man and the Africans. It is characterized by oppression and brutality. The head teacher nicknamed 'lesson one' closely mirrors the colonizer. He was a terror with his cane. When Kariuki and his mates fail to go to school on the day of the raid, he does not pay attention to their excuses but administers four strokes of the cane to each one of them. In Kariuki's assessment 'one whack from his cane was worth ten from any of the other teachers' (p6). In the head teacher's view, the boys had not gone to school the previous day because they were lazy, dirty and stupid 'ihii'- uncircumcised boys. The choice of adjectives projects the headmaster's contempt for the boys. His superiority is thus emphasized in his dismissal of them. His creed, which gave no leeway for absenteeism, emphasizes the brutality to which he subjected the pupils. Kariuki confesses that as uncircumcised boys going to school in Majengo primary, they lived a terrified life. Peace was something they merely dreamt about. This confession finds confirmation in the harassment he experienced both at school and at home.

During his encounter with the head teacher, Kariuki contemplates jumping out through the window and never going back to school, ever again. What stops him was the fact that his father's cruelty matched that of the head teacher. He says, 'I knew my father would finally kill me and send my body to school as usual, in uniform and on time. The headmaster would still be there, waiting' (p4) The children are thus portrayed as being at the mercy of the adults - their colonizers, who present them with no other option but to obey or else meet unpleasant consequences.

The end of the school term was a time for setting scores; however Kariuki could not partake in a fight because he did not know how to fight without injuring someone or getting injured himself. In either case his father would beat him thoroughly. His father's harshness thus forces him to take a neutral stand which sets him apart from other boys. 
The relationship between Kariuki and his mother is no better. Kariuki was never in a hurry to get home from school because his mother ' had an endless list of chores to keep an idle boy busy'(p10). The list kept growing and the only way for Kariuki to save himself was to get home late. The adults thus emerge as oppressors of children presenting them with no option to explore personal interests. They dictate the children's mode of behavior and course of their action by curtailing their freedom.

The relationship between the adults and the children is thus likened to that of the colonizer and the colonized. In this way, the rift between the adult world and the children's world is magnified. Even after Nigel rescues Kariuki from drowning, Kariuki's mother who had turned up at the river to find out why he had delayed in fetching the water, hauls him onto the bank gives him a thorough shaking and demands to know what had happened to the water she had sent him for. She then thrusts the bucket into Kariuki's hands with the condition that he had to get the water home before she herself got there. Unmoved by Kariuki's accident, she turns and hurries home indifferent to the boy who was panting and shivering from cold behind her. She then orders him to fetch firewood. It is only when Kariuki realizes that she has no other chore lined up for him that he sneaks out of the hut and heads back to the river.

His encounter with his father while on his way to the river promises no comfort either. On learning that Kariuki had fallen into the river, he raps him on the head with his knuckles. He does not wait for Kariuki's explanation but jumps to the conclusion that the boy had gone out fishing. The children thus constantly suffer at the hands of the adults who try to define for them the path to follow irrespective of the children's feelings. As Kariuki confesses, everything his father told him was an order. In fact he could not remember his father ever telling him anything in a friendly way.

His tribulations worsen when accepts the fish given to him by Nigel only to be confronted by Bwana Ruin. With Nigel out of sight, he throws away the fish for fear of his parents' reaction. Unfortunately, Bwana Ruin sees him and orders him to retrieve it from the bush then leads him back to the farm believing that Kariuki had been out fishing at the river. Kariuki's father like Bwana Ruin does not hesitate to conclude that his son was out fishing and without giving him a chance to explain himself, he gives him a slap that catches him off guard and knocks him into a rose bush. He then hauls him out by the ear and gives him a painful rapping on the head with his knuckles.

The white man and his cook are thus unified in their mistreatment of the boy as a result of their false assumptions. Kariuki is only saved from his predicament by Nigel who confesses to having given him the fish. He then goes home to face the wrath of his mother, certain that there was something he had forgotten to do. Kariuki's world is thus depicted as a little prison. This incarceration having been imposed by an endless list of don'ts imposed by the white man on the native boys and reinforced by their parents back at home. He is not at liberty to choose his friends or do what he wants at his own discretion. To add insult to injury, his brother Hari whom he greatly adored had the habit of slapping him on both cheeks at the same time leaving the brain fairly scrambled.

As a child Kariuki's world is characterized by a lot of naiveté, he does not know who Mau Mau are and when he first encounters them at the duck pool, he likens their body odor to buffalo. He uses what comes most naturally to him to understand his environment. He remembers the smell of buffalo that hung over the village for several days after Bwana Ruin shoots down one, takes the best part of the meat for his dog and allows the villagers to take the remaining part for themselves. This act also dramatizes the superiority of the white man to the blacks. He does not eat buffalo meat but reserves the best part for his dog. The villagers on the contrary scramble for the remnants.

In a separate incident when he encounters the Mau Mau at the duck pool, he is frightened by one of them who decided to send him to Hari, his brother. As he tries to run away from the men and go home, one of them grabs him and lifts him off the ground. Kariuki likens this act to the way 'jimis' shook rabbits in their teeth, once again drawing from images in his environment.

His naiveté is further revealed in his acceptance of Bwana Ruins word as law. He refuses Nigel's suggestion to fish because fishing was not allowed. He had believed Bwana Ruin's claim that Mau Mau were bad people who stole sheep and killed people without question. He is thus surprised that Bwana Ruin could be characterized with such traits as lies as the Mau Mau claim.

Nigel too is surprised that an individual could own a river since where he came from rivers were for everyone. Nigel's revelation thus exposes the absurdity in Bwana Ruin's claims to ownership of the river- a natural resource. It reveals Ruin as selfish and oppressive, wielding excessive power over the natives. For Kariuki this was an unquestionable fact. Those found fishing in the river were not only whipped but their fathers were also dismissed from their jobs. This too highlights Ruin's oppression; errant children's fathers suffer for crimes that they themselves did not commit. This in turn translates into suffering of whole families.

Kariuki views England as a little boy's paradise. He is fascinated by the liberty and equity enjoyed by the people there. This confirms the colonizer's position at the top. The imperial power is the superior culture. And indeed as Kariuki 
observes, virtually everything they used was made in Britain. In effect, the first words Kariuki had learned to read were 'Made in Great Britain.'

Of note however is the fact that the children's world stands in total contrast to that of the adults. This difference is manifest right at the point of the initial encounter between the two children. Though he has just met Kariuki, Nigel calls out to him and smiles a genuine, friendly smile. However, despite the friendly rapport between them, Kariuki soon realizes that Nigel differed from him in certain ways. For instance, for him, the 'koe' fruits which he picks up from the 'Mokoe' tree he had climbed are sweet so he decides to stay up the tree and have a few more. On the contrary, when he throws down a few to Nigel to eat, Nigel tastes one and spits into the river then throws away the rest. Kariuki who had started to believe that the white boy was just a boy like him and would naturally love the taste of the wild fruit is disappointed. From Nigel's reaction, the writer clearly marks out the separate worlds of the two boys. Their association thus suggests a negotiation of a hybrid culture.

Despite such differences, they erect no barriers or inhibitions and prejudices between them. Instead, their revelations to each other open up new horizons in their understanding and appreciation of each other's world. They strike up instant friendship irrespective of race. Kariuki is quick to come to Nigel's assistance when his fishing line gets stuck in the Mokoe tree. In turn Nigel springs to rescue Kariuki from drowning when he slips and falls into the river. This reveals an attempt at syncretism.

At a personal level thus, the relationship between Nigel and Kariuki depicts hybridity as a site of social reconstruction. The claim to superiority is downplayed by the fact that each child discovers something new in the other thus resulting to a hybrid conception of the world. Previously, Kariuki had learnt about Britain from the labels attached to the stationery, crockery and the implements they used. His assumption however, was that England was a place so near that he and Nigel could go fishing there one evening.

From Nigel's revelations, Kariuki is surprised that Britain is further than Loldaiga Hills or the horizon, and that one could not walk there. He is impressed at the fact that Nigel had travelled by plane and that the plane was at Nairobi -a place he himself had never visited. He had only come across the word Nairobi in school books and Nigel was therefore the first the person he had met who had been to Nairobi. Nigel's world thus fascinates Kariuki for it is a world totally alien to his.

In this way Meja Mwangi juxtaposes the child characters' world views. Nigel enjoyed a considerable measure of freedom whereas Kariuki was totally denied the same. He lived in constant fear of his parents and the white man. He could not go fishing because all the fish belonged to Bwana Ruin, a fact that greatly surprises Nigel. Unlike Nigel, he does not know how to swim. Despite these differences, the two complement each other very well. Nigel even offers to teach Kariuki to swim.

In order to find time for this exercise, he offers to help Kariuki chop the wood and since this is a task he had never performed before, Kariuki teaches him how to hold the axe and to step on one end of the wood so that it would not snap back and knock his head off. The two characters are thus initiated into each other's world resulting in a hybrid formation.

Nigel is shocked at the brutality that seemed to characterize Kariuki's world. In Kariuki's explanation, 'a village boy's life was very difficult. Everyone from your father to your teacher, anyone who could do so, beat the day light out of you. There was no hope of peace till you grew older and got circumcised and became a man' (p33). Kariuki is thus accustomed to brutality for it was part and parcel of his life. Nigel's world is different, his parents never beat him and the teachers hardly ever caned anyone, only wrong doers were punished by the head teacher.

Besides this brutality, there was general contempt that went with status. The social stratification of the village was such that all the white people were at the apex, next in rank were the village men, followed by women and girls, the village goats and sheep came next after which there were uncircumcised boys and lastly the mongrels. So low were the mongrels that they were generally simply called dog or 'jimy'. Circumcision was thus an important rite because it elevated the boys from insignificance to recognition. It was only after undergoing this rite that one was saved from unwarranted brutality.

The only peaceful moment for Kariuki appears to be during his forest excursions. The forest presents a world in which he is master. It was a space of tranquility and freedom. On the contrary, Nigel had never been in a forest as big and wild as the one they went to. He is thus awed by everything he sees 'the birds the trees, the insects were all new to him' (p35). Soon it was clear to Kariuki that he knew as little about Kariuki's world as Kariuki knew about his. Their relationship is thus symbolic of the merging of the two poles. The forest thus becomes a space of mutual borrowing and social renewal.

Through this exposure Nigel immerses himself into Kariuki's world and 'drunk on the sounds and smells of our magical forest, he ran about like an excited puppy' (p35).He suggests that they play Tarzan, a game Kariuki knows 
nothing about. Kariuki had expected Nigel to teach him to swim yet Nigel declares that he forgot his swimming shorts. Kariuki is surprised at the fact that Nigel swam in shorts for he himself had only two pairs of short, the one he wore at school and the one he wore at home. This reveals the sophistication that characterizes Nigel's world. Not embarrassed by the other's presence, Kariuki takes off his shirt and shorts and jumps into the ice cold water. Nigel follows suit. They then try fishing with bare hands as Nigel suggests but they fail. Finally they settle for the purple 'koe' fruits. Nigel's acceptance of the 'koe' fruits which initially had been unpalatable to him suggests his total immersion into Kariuki's world.

This excursion thus becomes a moment of bonding. Suggestions are floated and adopted by the two friends. They negotiate their differences carefully and take up what they find suitable for both of them. Nigel is totally naive about Kariuki's world. He had read a lot about nature but the excursion gives him practical grounding in actual practice. Kariuki on the contrary is wiser. He had been out hunting in the forest before. He enlightens Nigel on the kind of fruits to eat and those to avoid, cautions him against snakes when he tried to catch a cobra that speeds past by its tail, warns him against pursuing a buffalo because buffalo killed both dogs and people. For Kariuki, Nigel's stupidity and ignorance seemed to have no end.

The social disparity between the two children is Meja Mwangi's way of scorning power relations among races. Each is master of his world. Nigel is worried about the dogs that run after the buffalo whereas Kariuki is confident that the dogs would find their way home in due course. This encounter also clears Kariuki's misconceptions about the white man. He is surprised to discover that Nigel could not see in the dark just like him. Equally surprising is the discovery that Bwana Ruin too could not see in the dark and that he could neither know what someone else was thinking without the person's confession to him nor see into other people's heads and hearts. As Nigel clarifies, Bwana Ruin was just like any other man. The difference in the color of the eyes was a natural phenomenon for which Nigel could not offer an explanation.

The association between the two boys thus attempts to erase the binary distinctions between them. Kariuki realizes that despite the differences in the color of their skin and eyes, they were basically the same. However, such distinctions were not easily erasable. The position of the white man at the top remained defined. In church people sat according to the social hierarchy so that the Ruin family and all white people sat on the front row and had cushions to sit on and others to kneel on. The teachers sat behind them with no cushions to sit on or kneel on. The rest of the people came next. Men sat to the right hand side of the church, the women and girls sat to the left whereas the boys could not sit at all.

Such inequalities also depict interplay of power relations. In as much as Kariuki discovered that white men were human like everyone else, they always remained superior to the black man. Kariuki and his mates fail to understand how the head teacher who in their view was God's authority on earth was not allowed to sit with the white people construed as holy by him. The prevailing assumption being that the whites were close cousins of Jesus. He thus delights in having Nigel as a friend for this elevated him above other boys who unlike him had no friends at the top. In essence thus Kariuki recognizes the difficulty of completely erasing the boundaries between cultures.

Having been initiated into hunting, Nigel develops a craze for the sport; he thus visits Kariuki quite often to coax him into going hunting with him. He even helps Kariuki with harvesting of beans and potatoes with the hope that this would hasten the completion of the exercise so that they would find time to go hunting. He gives up his smart suits and opts for khaki shorts and shirts which were more ideal for harvesting. He becomes a common figure in Kariuki's home. He takes off his shoes and walks barefoot to see what it felt like. In turn Kariuki walks about in Nigel's shoes so as to have a feel of what it was like to wear shoes. This relationship thus opens up new horizons in the experience of both children.

Nigel even goes to the extent of eating ugali, a dish foreign to those of his culture. This makes him the center of attention. In disbelief, the villagers stare on at him. The previous assumption being that white people only ate cakes and sweets. Nigel's relationship thus helps to clear myths previously held onto by the blacks. This makes him more authentic in their eyes since they realize that he was human like the rest of them. The village boys take this a notch higher, 'every tough boy and bully now has to wrestle Nigel to the ground or thrash him thoroughly so as to improve their own rating in the villages mean boys club' (p56). In turn Kariuki has more difficulty protecting his little white man, sometimes getting quite badly bashed up himself. This is a signal of their total acceptance of Nigel as one of their crowd.

Kariuki's father on the contrary is not at ease. Nigel's close association with his son threatened his job security. He thus sternly warns Kariuki against any further liaison with Nigel. This however falls on deaf ears. It was impossible to keep Nigel away from Kariuki's compound. He visited Kariuki every day and on every occasion pleaded to be taken hunting. He said Kariuki was his only friend and that he found it boring staying with old people at home. Kariuki refrains from going hunting for sometime but soon give in to Nigel's demand, the first time to avert Nigel's attention from the ugali 
his mother was preparing for lunch. He is terrified of possible negative repercussions that were likely to arise if he defied his father's orders and let Nigel eat the ugali.

Later the two go hunting unconditionally, only this time they are careful to cut through village alleys and by ways to avoid running into Kariuki's father or anyone who might object to their expedition. Contrast is drawn between the hunting expedition on which the children go on their own and those on which Nigel accompanies Bwana Ruin. On occasions when the children go out on their own they are carefree and much excitement prevails, they run around wildly and uninhibited, accompanied by several mongrels who add to the din. This contrasts expedition on which Nigel accompanies Bwana Ruin. They go far into the bush in a roofless land rover, drive up to the animals and stop the vehicle after which Bwana Ruin shoots the animals through the head, loads the carcasses onto the vehicle and brings them their back for his dogs. Nigel preferred the other kind of hunting whereby there was a lot of running. The children are thus depicted as comfortable in their own world away from the adults.

Between the two friends, all barriers are broken. Theirs is a genuine friendship and each is concerned about the welfare of the others. When Nigel gets lost in the forest, Kariuki becomes genuinely alarmed, he cannot eat or stand still for a minute, he even contemplates suicide. He however does not confide in anyone and when questioned of Nigel's whereabouts he denies any knowledge of where he could be. He spends a miserable night plotting how he would go in search of Nigel the following day. He even resolves to run away to the land of the Dorobo if he failed to find Nigel. Despite his aching foot he sets off at the earliest opportunity to search for Nigel covering vast ground. He does not give up the search until he finally discovers him in a cave, trussed up and gagged then covered under several sheepskins. Unfortunately, his attempt to rescue Nigel is foiled when they find themselves face with Nigel's kidnappers. This time they are both dragged back to the cave and are thus united in their troubles.

Nigel's loyalty to Kariuki is depicted when he saves him from a blow from Hari by warning Hari not to hit Kariuki lest he hurts him. Later on when Hari comes back to rescue them, Nigel offers Kariuki his shoulder to lean on for Kariuki's foot was still painful. This act is later repeated when Kariuki, overwhelmed by Hari's death seeks solace at the duck pond. Mysteriously Nigel is able to find him. He sits silently beside Kariuki for a long time sharing his sorrows in the silence until it was nearly dark 'and cold radiated out of the river like heat from a fire'(P103).When Nigel finally puts his arms around Kariuki, Kariuki sobs uncontrollably for a long time before he calms down.

The final proposition at syncretism comes when Nigel declares to Kariuki that if he had a brother he would give him to Kariuki so that Kariuki would not miss Hari so much. Naïve as the statement may sound; it could be Meja Mwangi's statement against racial prejudice. It expresses the fact that basically all human beings were the same. The feeling of brotherhood should transcend differences of color. To Nigel, his brother would serve Kariuki just as well and fill the void Hari's death had left. From Nigel's statement, Kariuki realizes what a true and good friend he had found. When they finally leaves the duck pool, Nigel offers Kariuki his shoulder to lean on since Kariuki's aching foot made it difficult for him to haul himself up the steep incline. In Kariuki's summation, 'That was how they got back to the village walking shoulder to shoulder as true friends ought to walk'(p104).In this way, the bond between the two is cemented.

\section{Conclusions}

Hybridity in Meja's text is depicted at various levels. On one hand, there is cultural hybridity through attempts at syncretism as depicted in the relationship between Kariuki and Nigel. This relationship depicts the dismantling of cultural and racial difference in favor of a brotherhood which unfolds as a result of the two characters' immersion into each other's world view.

Their innocence, naiveté, sincerity, craze for adventure and natural curiosity become important recipes that propel them towards a common understanding. They thus establish a common ground for mutual borrowing which in turn expands their world view and perception of people and events around them. Hybridity thus becomes a site for social reconstruction from which the two characters emerge wiser and more enlightened through practical experience.

The adult world stands for stark contrast to the children's world. It is characterized by suspicion, insecurity, tension, contempt, brutality and racial prejudice. It largely revolves around the interplay of power relations with the colonial settler at the top and the natives at the bottom. The natives are harassed at the pleasure of the colonizer who has grabbed their land and has sworn that they would not have it back unless over his dead body. In turn, the natives have taken to the bush as Mau Mau for this seems to be the only way through which they can reclaim their freedom.

The adults always impose their will on the children for instance, Bwana Ruin warns Nigel against teaching Kariuki to fish. Nigel's grandmother would not allow Nigel to touch anything. She is always scared that he will hurt himself. Kariuki's mother always has a list of chores lined up for him as a way of keeping him busy. Kariuki's father warns him 
against associating with Nigel; he is not to allow Nigel to eat ugali because white people do not eat African food, lest they fall sick. He warns him against fishing for this might make him loose his job.

As a result colonization is depicted at two levels that is, the Africans are colonized by the whites represented by Bwana Ruin. At another level children are colonized by all adults, they are denied the freedom to pursue their own interest. They provide a spot through which the adults vent out emotional insecurity. However it is notable that even in such strict conditions, the children always maneuver their way around the adults and pursue their own self interest. Thus Nigel is always a frequent visitor in Kariuki's home. Despite Kariuki's father displeasure at such visits, he still associates closely with Kariuki and regards him as his only friend despite his grandfather's dislike for such associations. Likewise, Kariuki is always able to secretly slip out of his mother's compound to meet Nigel at secret rendezvous contrary to his father's warning. He has developed evasive responses -nowhere, nothing and no one as a survival technique.

The hunting expeditions thus go beyond the literal hunting for wild game. They are symbolic of the hunt for new knowledge and exploration of new horizon through revelations by the new friends. In this way, a sense of intimacy develops between them as each imbibes from a world previously alien to him. Nigel had read a lot about nature but during the expeditions he encounters something bigger and more exciting than he had imagined. Likewise, stereotypical perceptions previously held by Kariuki are erased. The text thus becomes a journey of maturity for the protagonist. His naïve perceptions are projected against the background of serious issues of oppression, harassment, exploitation, poverty and brutality that characterize the colonial regime. The child narrator thus provides an objective view of the unfolding events without any imposed biases.

\section{References}

Graneheim, U., \& Lundman, B. (2004). 'Qualitative Content Analysis in Nursing Research: Concepts, Procedures and Measures to Achieve Trustworthiness.' In Nurse Education Today, vol.24, pp.105-112.

Kehinde, A. (2004). 'Post Independence Disillusionment in Contemporary African Fiction: The Example of Meja Mwangi's Kill Me Quick'. In Nordic Journal of African Studies. 13(2) p228-241.

Kehinde, A. (2005). 'Aesthetics of Realism: The Image of Postcolonial Africa in Meja Mwangi's Going Down River Road'. Retrieved from: http://arts/bunel.ac.uk/gate/entertext/4.2/kehinde.pdf

Khorana, M. (1998). (Ed.).Critical Perspective on Postcolonial Africa Children's and Young Adult Literature. Westport, CT: Green Wood Press.

Larangy, E. (2008).The Imperial Archive: Key Concepts in Postcolonial Studies. Retrieved November, 2011 from: www.qub.ac.uk/ schools/.../imperial/.../hybridity.htm

Lye, J. (1998). Some Issues in Postcolonial Theory. Retrieved from: http://www.jeeves.brocku.ca/english/courses/4F70/postcol.php

Macmillian, J., \& Schumacher, S. (1997). Research in Education: A Conceptual Introduction (4th ed.). New York: Harper Collins College Publishers.

Mcguire, H. (2006). 'Meja Mwangi: Writing Lively Stories set in Colonial and Post colonial Kenya.' In Sankofa. Vol.5. p85

Nachmias, C. F., \& Nachmias, R. (2008). Research Methods in the Social Sciences (5th ed). London: Hodder Education.

Punter, D. (2000). Postcolonial Imaginings: Fictions of a New World Order. Lanham, Maryland: Rowman and Littlefield.

Rose, J. (1984). The Case of Peter Pan or The Impossibility of Children's Fiction. London: Macmillan.

Sharp. J. (2008). 'Can the Subalterns Speak?. In Geographies of Postcolonialism. Sage publications.

Walker, L. (2005). The Mzungu Boy. Toronto On: Ground Books. Retrieved from: http://www.mejamwangi.com/ the_mzungu_boy_reviews.htm 